\title{
Obstruktivne motnje dihanja v spanju pri otrocih
}

\section{Obstructive sleep apnoea in children}

Nina Božanić Urbančič

\section{Izvleček}

Obstruktivne motnje dihanja v spanju so pri otrocih pogosta težava in imajo lahko pomembne srčno-žilne, nevrokognitivne in presnovne posledice. Najpogostejša motnja je obstruktivna apneja v spanju. Gre za delno ali popolno obstrukcijo zgornjih dihal s posledičnimi hipoksijo, hiperkarbijo, povečanim dihalnim naporom, poudarjenimi spremembami intratorakalnega tlaka in fragmentiranim spancem. Patogeneza še ni povsem jasna. Diagnostična metoda izbire je polisomnografija.

Blage oblike zdravimo z zdravili (antilevkotrieni in nosnimi glukokortikoidi). Zelo uspešna operativna metoda zdravljenja otrok z obstruktivnimi motnjami dihanja v spanju, ki imajo adenotonzilarno hipertrofijo, je adenotonzilektomija. Pri otrocih z visokim indeksom telesne mase, visoko stopnjo obstrukcije ali pridruženimi boleznimi je po operativnem zdravljenju večja verjetnost rezidualne obstrukcije. $V$ teh primerih otrokom pomagamo z masko s kontinuiranim pozitivnim zračnim tlakom.

Ključne besede: apneja v spanju, obstruktivna, otrok, polisomnografija, zdravljenje.

\begin{abstract}
Obstructive breathing disorders in sleep are a common problem in children that can have serious cardiovascular, neurocognitive, and metabolic consequences. The most common disorder is obstructive sleep apnoea, which is characterised by partial or complete obstruction of the upper airway, with resultant hypoxia, hypercarbia, increased respiratory effort, pronounced intrathoracic pressure changes and sleep fragmentation. The pathogenesis is not yet clearly understood. The diagnostic method of choice is polysomnography.

Mild forms of obstructive sleep apnoea can be treated medically (leukotriene receptor antagonists and nasal glucocorticoids). Adenotonsillectomy is a very efficacious surgical treatment method in children with obstructive sleep apnoea and adenotonsillar hypertrophy. Children with a high body mass index, high-grade obstruction or other associated conditions are more likely to have postoperative residual obstruction. These children are treated by the application of continuous positive airway pressure through a mask.
\end{abstract}

Key words: sleep apnoea, obstructive, child, polysomnography, treatment 


\section{Izhodišča}

Spanje je fiziološka funkcija, ki se z nevrofiziološkega in vedenjskega vidika v življenjskih obdobjih spreminja. Proces je posledica dozorevanja različnih možganskih struktur. V razvoju prihaja do kontinuiranih fizičnih in nevrofizioloških sprememb ter sinaptičnega remodeliranja, kar je osnova plastičnosti možganov, ki je tipična za razvojno obdobje in za obdobje spanja (1).

Motnje dihanja v spanju lahko razdelimo na obstruktive motnje dihanja v spanju (angl. obstructive sleep apnea, OSA), centralno apnejo v spanju, hipoventilacijo in hipoksemijo v spanju. Vsem je skupna motnja dihanja ali ventilacije $v$ spanju. Diagnostično in pri dolgoročnih posledicah včasih meja med centralno in obstruktivno apnejo v spanju ni povsem jasna (2).

\section{Definicija}

OSA je najpogostejša motnja dihanja v spanju. Gre za delno ali popolno obstrukcijo zgornjih dihal s posledičnimi hipoksijo, hiperkarbijo, povečanim dihalnim naporom, poudarjenimi spremembami intratorakalnega tlaka in fragmentacijo spanca (3).

Med običajne simptome in znake OSA uvrščamo smrčanje, premore v dihanju, povečan dihalni napor, paradoksne gibe prsnega koša, potenje, nemiren spanec in dihanje na usta. Da bi vzdržali odprto dihalno pot, nekateri otroci med spanjem hiperekstendirajo vrat. OSA se pojavlja pri $11-5 \%$ (4) otrok v starosti 2-8 let (3).

Dejavniki tveganja za razvoj OSA pri otrocih so adenotonzilarna hiperplazija, povečana telesna teža, nedonošenost, afriško-ameriško poreklo, kraniofacialne anomalije (kot pri Pierre-Robinovem sindromu, trisomiji 21, Prader-Willyjevem sindromu) in živčnomišične bolezni (5).

Otroci in dojenčki z motnjami dihanja $v$ spanju imajo lahko številne nevro- loške in vedenjske posledice. Najbolj znane so pešanje šolskega uspeha, jutranji glavoboli, spremembe razpoloženja, nočna enureza, motnje pozornosti (hiperaktivnost), učne težave, agresivnost in nenavadno obnašanje (5). Še vedno ne vemo, ali tako zgodnja motnja dihanja lahko pripelje do dolgoročnih motenj obnašanja (2).

\section{Mehanizmi nastanka}

Patofizioloških mehanizmov nastanka motenj dihanja v spanju pri otrocih še niso dobro raziskali. V kliničnih raziskavah so odkrili določene razlike med otroki in odraslimi bolniki.

1. Dojenčki so praviloma odvisni od dihanja na nos. Na usta dihajo samo med jokom in v primeru nosne obstrukcije.

2. Otroci in dojenčki imajo resnejše klinične posledice, ki so povezane z blažjimi oblikami motenj dihanja v spanju.

3. Otroci in dojenčki z OSA imajo manj kortikalnega vzburjanja.

4. Pri otrocih se lahko pojavi obstruktivna hipoventilacija. Gre za perzistentno delno zaporo zgornjih dihal, ki povzroča hiperkapnijo in/ ali hipoksemijo.

5. Pri otrocih in dojenčkih se obstrukcija dihanja v spanju pojavlja večinoma med fazo REM (angl. rapid eye movement), v drugih fazah spanja pa je običajno ni (2).

\section{Diagnosticiranje}

Pri diagnosticiranju sta pomembni natančna anamneza (vključno $z$ iskanjem podobnih težav pri drugih družinskih članih) in anamneza spanja. Pri diagnosticiranju uporabljamo tudi specifične vprašalnike. Klinični pregled zajema natančen pregled zgornjih dihal (najbolje s strani specialista otorinolaringologa) in iskanje znakov kronične hipoksije, kraniofacialnih anomalij in dismorfnih znakov $(5,6)$.

Polisomnografija (PSG) ali kontinuirano merjenje srčno-žilnega delovanja (angl. continuous monitoring of cardiorespiratory function, CMCRF) je zlati standard $v$ diagnosticiranju motenj dihanja v spanju. Po priporočilu Ameriškega torakalnega združenja je PSG indicirana vedno, ko diagnoze OSA ne moremo postaviti samo z neposrednim opazovanjem dihanja $v$ spanju (7). Ameriška akademija pediatrov $v$ smernicah diagnosticiranja in zdravljenja navaja 65-odstotno pozitivno napovedno vrednost za anamnezo in 46-odstotno napovedno vrednost za klinični pregled, zato pri vseh otrocih s simptomi OSA priporočajo nadaljnje preiskave (3). Izvid PSG je izjemnega pomena predvsem v primerih atipične OSA, pri sindromu zvišanega upora zgornjih dihal in obstruktivni hipopneji ali če je ugotavljanje faz spanja in pojava težav pomembno za postavitev diagnoze (2). Izvedba PSG zahteva hospitalizacijo, preiskava pa je draga in tehnično zahtevna, zato ponekod ni dostopna. Alternativa je kardiorespiratorna poligrafija (CRPG), ki izključuje nevrofiziološke meritve in ima pri otrocih pri diagnosticiranju klinično pomembne OSA 90,9-odstotno občutljivost in 94,1 -odstotno specifičnost (8). Ker se pri otrocih motnje dihanja v spanju pojavljajo predvsem proti koncu noči, nekateri zagovarjajo preiskave, ki jih lahko opravimo v domačem okolju. CRPG je obetajoča alternativa polisomnografiji (8). Ostale (bolnišnične) metode vključujejo nadzor nad dihalnimi funkcijami, diafragemsko elektromiografijo (EMG), ezofagealni balon, aktimetrijo in EMG brade. Najpogostejše so metode, ki za razlikovanje med centralno in obstruktivno apnejo uporabljajo impedanco prsnega koša oz. trebuha in termistorje za zaznavanje dihanja na nos (2).

Najbolj smiselno se zdi, da otroka s sumom na obstruktivno motnjo dihanja v spanju glede na anamnezo, kli- 
nične simptome in znake ter klinični status napotimo na PSG k specialistu pediatru, ki se ukvarja s spanjem, ali k specialistu otorinolaringologu.

\section{Zdravljenje}

Pri zdravljenju lažjih oblik OSA se poslužujemo zdravil (intranazalnih glukokortikoidov in antilevkotriena montelukasta) (3). Pri otrocih s hipertrofijo adenotonzilarnega tkiva, ki povzroča OSA v nosnem delu žrela, vidimo močno povečano žrelnico, ki popolnoma (ali skoraj popolnoma) zapira hoani, medtem ko se nebnici v mediani liniji stikata ali praktično stikata. Takšni otroci praviloma dihajo skozi usta. Dokazano je, da otroke $z$ adenotonzilarno hipertrofijo večkrat (po nepotrebnem) zdravimo z antibiotiki (9). Povečane nebnice namreč niso vedno tudi vnete (ni rdečine). Če je pri bolniku z OSA prisotna hipertrofija adenotonzilarnega tkiva, je indicirana adenotonzilektomija. Pri otroku, ki nima pogostih tonzilitisov, praviloma opravimo adenotonzilotomijo (6). Pri tonzilektomiji odstranimo nebnici v celoti skupaj z vezivno ovojnico, pri tonzilotomiji pa le del nebnic, ki oži prehod proti ustnemu žrelu. Tonzilotomija je manj invaziven poseg in ga spremlja tudi manj zapletov (6). Starši večkrat hitreje pristanejo na tonzilotomijo, saj verjamejo, da bo ostanek nebnic še naprej opravljal svojo imunološko nalogo. Nedvomnih dokazov za takšne trditve v literaturi ni. Otroke po adenotonzilektomiji praviloma spremljajo na primarni ravni. Izbrani lečeči pediater se v primeru ponovitve težav lahko odloči za ponoven otorinolaringološki pregled ali za multidisciplinarno obravnavo. Glede na možne intraoperativne in pooperativne zaplete adenotonzilektomije (predvsem krvavitve) sodobne raziskave iščejo možne pozitivne učinke protivnetnih zdravil, ki bi lahko nadomestila operativno zdravljenje. $V$ raziskavah dolgoročnih pozitivnih učinkov nosnih glukokortikoidov in antilevkotrienov zaenkrat niso dokazali (10). Delež otrok z rezidualno OSA po adenotonzilektomiji ocenjujejo na 13-73 \%. Dejavniki tveganja za vztrajanje težav kljub operativnemu zdravljenju so visoka telesna teža, huda stopnja obstrukcije pred operacijo, starost več kot 7 let, astma, kraniofacialne anomalije, kromosomski defekti in živčno-mišične bolezni (3). Pri otrocih brez adenotonzilarne hipertrofije in pri tistih, ki odklanjajo operativno zdravljenje, je indicirano zdravljenje s pozitivnim tlakom kisika. Kot otrokom bolj prijazno alternativo nekateri ponujajo zdravljenje $z$ visokim pretokom kiska preko nosne kanile. Zaradi tehničnih zahtev zdravljenja z masko, ki zagotavlja kontinuirano pozitiven tlak v dihalnih poteh (CPAP) le, če ne pušča, je pri otrocih alternativna oblika zdravljenja zdravljenje z visokim pretokom kisika, ki zagotavlja kontinuirano pozitiven tlak v dihalnih poteh s posebnimi nosnimi nastavki, ki jih otroci prenašajo bistveno bolje kot zdravljenje z masko, ki ne sme puščati (kot je potrebno pri (PAP). Otroci s CPAP in/ali zdravljenjem z visokim pretokom kisika potrebujejo dolgotrajno multidisciplinarno obravnavo in spremljanje. Odločitev o uvedbi takšnega zdravljenja je zahtevna, saj terja dolgotrajno izobraževanje in odlično sodelovanje med bolnikom, starši in zdravstvenim osebjem ter s seboj prinaša pomembne izzive in omejitve pri vsakodnevnem življenju bolnika in njegove družine.

Obravnava dojenčkov in otrok z motnjami dihanja v spanju je odvisna od bolnikove starosti in hkrati tudi od številnih drugih vpletenih dejavnikov.

\section{Zaključek}

OSA zahteva multidisciplinaren diagnostični pristop, natančno diagnosticiranje pa je osnova za učinkovito in hitro zdravljenje. Patogenetski mehanizmi motenj spanja pri otrocih in dejavniki, ki vplivajo na fenotipsko variabilnost bolezni, za zdaj niso znani in jih bo morda mogoče odkriti v nadaljnjih raziskavah.
Literatura

1. Lo Bue A, Salvaggio A, Insalaco G. Obstructive sleep apnea in developmental age. A narrative review. Eur J Pediatr 2020; 179: 357-65.

2. Neubauer D, Osredkar D, Paro-Panjan D, Derganc $M$. Neurophysiological studies during early life. Pediatriki 2009; 72: 259-69.

3. Grime C, Tan HL. Sleep Disordered Breathing in Children. Indian J Pediatr 2015; 82: 945-55.

4. Marcus CL, Brooks LJ, Draper KA, Gozal D, Halbower AC, Jones J et al. Diagnosis and management of childhood obstructive sleep apnea syndrome. Pediatrics 2012; 130: e 714-55.

5. Neubauer D. Cardiorespiratory studies and some syndromes of early cardiorespiratory dysfunction. Zbornik predavanj- Poslijediplomski tečaj stalnog medicinskog usavršavanja I katergorije s međunarodnim sudjelovanjem. Poremećaji ventilacije "Sleep apnea" Komiža 14.-16. 5 2009

6. Urbančič J. Obstruktivne motnje dihanja med spanjem pri otrocih - Zbornik predavanj: Otorinolaringološke dileme $v$ ambulanti na osnovni ravni: izbrana poglavja 5. Ljubljana: 2013. Str. 63-68.

7. American Thoracic Society. Standards and indications for cardiopulmonary sleep studies in children. Am J Respir Crit Care Med 1996; 153 : 866-78.

8. Kingshott RN, Gahleitner F, Elphick HE, Gringras $\mathrm{P}$, Farquhar $\mathrm{M}$, Pickering RM et al. Cardiorespiratory sleep studies at home: experience in research and clinical cohorts. Arch Dis Child 2019; 104(5): 476-81.

9. Johnston J, McLaren H, Mahadevan M, Douglas RG . Clinical characteristics of obstructive sleep apnea versus infectious adenotonsillar hyperplasia in children. Int J Pediatr Otorhinolaryngol 2019; 116: 177-80

10. Kuhle S, Hoffmann DU, Mitra S, Urschitz MS Anti-inflammatory medications for obstructive sleep apnoea in children. Cochrane Database Syst Rev 2020; 17: 1.

Asist. Nina Božanić Urbančič, dr. med. (kontaktna oseba / contact person) Univerzitetni klinični center Ljubljana, Zaloška 2, 1000 Ljubljana, Slovenija in Medicinska fakulteta, Vrazov trg 2, 1104 Ljubljana, Slovenija e-naslov: nina.bozanic@kclj.si

prispelo / received: 20. 2. 2020 sprejeto / accepted: 13. 5. 2020

Božanić Urbančič N. Obstruktivne motnje dihanja v spanju pri otrocih. Slov Pediatr 2020; 27(3): 124-126. https://doi.org/10.38031/ slovpediatr-2020-3-03. 